growth of both flora and fauna. The drainage basins of these lakes contain alluvial deposits formed by lakes which existed earlier; at the present time these lakes have no outlet, and thus their chemical content is the result of the leaching of the surrounding soil and the concentrating of their inflows over a long period of time. Lakes Naivasha and Baringo $^{13}$ contain seventeen and forty parts per million, respectively.

The grey mbuga clays in the Kongwa area, referred to earlier, have high sulphate values. Mbuga is the local name for low-lying depressions in the ground which in the past probably contained lakes. These depressions have accumulated salts leached from the surrounding countryside. Borehole waters in this area contain very large amounts of sulphate, ranging from one hundred parts per million to two thousand parts per million.

Hot springs may contain large amounts of sodium and calcium sulphate; one in Northern Rhodesia ${ }^{14}$ contains one thousand and fifty parts per million, another in Uganda ${ }^{4}$ contains approximately five thousand parts per million. The Northern Rhodesian spring contains ninety parts per million of calcium, whereas the Uganda spring contains two thousand parts per million of calcium. As this spring flows into the Semliki River, and so into Lake Albert, it and other springs in the neighbourhood may be responsible for the relatively high value for calcium in this lake. At the same time, it is worth noting that, as recorded above, the value for sulphates in Lake Albert have been found to be less than two parts per million, indicating that most of the sulphate that finds its way into the lake is used up.

Some swamps in the Kigezi district ${ }^{15}$ of Uganda contain very large quantities of ferrous sulphate; these may receive water from some volcanic source.

Streams contaminated by washings from dumps formed by concerns smelting copper are rich in sulphates. Examples of these from Northern Rhodesia ${ }^{14}$ show values for sulphate ranging between four hundred and seven hundred and eighty parts per million, whereas streams near by are recorded as containing no sulphate. The refining process of copper is usually carried out by calcining the copper sulphide ore with lime; the waste product formed is mainly calcium sulphate. This by-product may prove to be a valuable fertilizer for fish farms and possibly for agricultural purposes. In this connexion it is worth recording that the smelters also discharge vast quantities of sulphur dioxide from their chimneystacks. The safe disposal of this gas presents some problems as it is not in Africa an economic proposition to convert all this sulphur dioxide into sulphuric acid, although this acid is in great demand in other parts of the world. Greater demands for sulphuric acid may soon arise in East Africa, including the need to produce superphosphates from rock phosphate. A by-product of this process is again calcium sulphate.

One generalization may perhaps be permissible in order to explain the apparent shortage of sulphates in Africa. In other parts of the world sulphates are usually derived from sedimentary rocks, mostly ancient marine deposits ; such rocks are rarely found in Africa. The fact that the only sources of gypsum in East Africa are those contained in the cretaceous deposits along the coast of Tanganyika Territory may serve to emphasize the point.

More data are required ; but the evidence we have at present indicates that many of the natural waters of Africa are short of sulphates, and some of the soils also. The main purpose of publishing this account is to arouse interest in what may be a most important problem, not only to those concerned with inland fisheries but also to those concerned with agriculture and animal husbandry.

${ }^{1}$ Beauchamp, R. S. A., Nature, 157, 183 (1946).

Beauchamp, R. S. A., Int. Rev. Hydrobiol., 39, 316 (1939).

"Ricardo, C. K., "Report on Fish and Fisheries of Lake Rukwa in Tanganyika Territory and the Bangweulu Region in Northern Rhodesia", 75 (London, 1939).

- East African Fisheries Research Organization, Annual Report, 1951.

"Graham, M., "The Victoria Nyanza and its Fisheries", 64 (London, 1929).

- Worthington, E. B., Int. Rev. Hydrobiol., 24, 348 (1930).

Stappers, L., Renseignements de l'Office Colonial (Bruxelles), No. 4 (1914).

- Hart, J. S., Publications of the Ontario Fisheries Research Laboratory, No. $72(1952)$.

- Storey, H. H., and Leach, R., Ann. App. Biol., 20, 23 (1946).

${ }_{10}$ Mehring, A. L., and Bennett, G. A., Soil Sci., 70, 75 (1950).

11 "Agriculture in the Sudan", 452 (Oxford University Press, 1948).

${ }^{12}$ Sturdy, D., et al., J. East Afr. and Uganda Nat. Hist. Soc., No. 45-46, (1933).

13 Beadle, I. C., J. Linn. Soc. (Zool.), 88, 207 (1932).

14 Government Analyst, Lusaka, Northern Rhodesia, in litt. (1952). 1* Chenery, M. E., Kawanda Research Station, Uganda, unpublished
report (1952).

\section{THE FIFTH PAKISTAN SCIENCE CONFERENCE AND THE PAKISTAN ACADEMY OF SCIENCE}

\section{BY SIR HAROLD HARTLEY, K.C.V.O., C.B.E. F.R.S.}

T February Dr. George Taylor and I, representing I the British Association, were the guests of the Pakistan Association for the Advancement of Science for its Fifth Science Conference at Lahore, and for a study tour of Pakistan. The Conference was opened by the Governor of the Punjab, who spoke of the progress that had already been made in the Punjab both in strengthening scientific education and in establishing a number of research laboratories which are attacking urgent problems such as water-logging and the salinity of agricultural land. He spoke of the need of Pakistan, an under-developed country, for scientists and engineers, and the help that international co-operation would bring. The president, Dr. Bashir Ahmad, vice-chancellor of the University of the Punjab, took as the subject of his address "Our Problems of Higher Education and Science". His main theme was the position of science in general education not merely for its material benefits but also for its unique function in guiding sound emotional development. Science, he said, is the systematic knowledge of Nature and her ways. That knowledge has cultural value which is as significant as that of philosophy, fine arts or literature. He made a strong plea that science should be a compulsory subject in the school curriculum. $\mathrm{He}$ emphasized the need of Pakistan for institutions of higher learning and science, which must remain free from political control in order to achieve their objectives.

The work of the Conference was done mostly in eight sections covering the main branches of science, engineering, agriculture and medicine. Many papers were read describing recent research work in universities and research laboratories in both Western and Eastern. Pakistan. Most of them dealt with applied 
science, and they showed what a realistic and successful contribution is being made to national development, particularly in agriculture, genetics, entomology, chemistry and economics.

In addition there were a number of general lectures ; for example, by Prof. H. J. Bhabha, director of the Tata Institute of Fundamental Research, on cosmic rays, by Dr. Taylor on south-east Tibet and on the work of the British Museum, and by myself on the art of discovery and on limiting factors in production.

The Conference was extremely successful. Large numbers of young students came to the meetings and were obviously keenly interested in the papers. Both during the meeting and after its close, the twenty. five foreign delegates were able to visit a number of research laboratories, including Dr. Chaudhury's new nuclear physics institute at the Government College, Lahore, which will be finished shortly, and the Punjab Agricultural College and Research Institute at Lyallpur, where a large programme of research is in full swing. It covers the main agricultural problems of Western Pakistan and much progress has been made in improving the strains and the methods of cultivation of the staple crops.

We then motored to Peshawar, where we saw the University and the fine engineering laboratory which will soon be completed. We visited the Khyber Pass, the Malakand and Dargai power stations, and the site of the hydro-electric scheme on the Kabul River at Warsak which will produce both cheap electric power and irrigate some 65,000 acres of land on the North-West Frontier, making it available for cultivation by the frontier tribes. Financial assistance from Canada under the Colombo Plan will enablo work on this site to start at once.

We were greatly impressed by the progress which is being made in the North-West Frontier Province under the dynamic leadership of the Chief Minister, Abdul Qayum, in education, hospitals, rural electrification and factories for the processing of agricultural products, like the sugar refinery at Bialpur. We went next to Rawalpindi to see the hill station at Murree, the Himalayan forest, and the ruined city of Taxila, with its fine Romano-Buddhist museum under the curatorship of Mr. Harundur Rashid.

In Karachi we saw the new University in its improvised home, the laboratories of the Department of Scientific and Industrial Research, where important researches have already started without waiting for full equipment, the Central Testing Laboratory, and the Cotton Research Institute. During our visit we were impressed by the excellent work which is being done in various centres by the British Council.

The most urgent problems of Pakistan, apart from her food shortage, seem to be supplies of irrigation water, drainage and electric power. These are all inter-connected, and it is to be hoped that the negotiations with the World Bank will soon result in engineering works for the control of the headwaters of the Indus, which could provide both perennial irrigation and ample power. The experience of irrigated zones in Egypt and Arizona suggests, however, that the problem of the salting up of the soil, which is becoming increasingly serious, will only be met by extensive drainage systems.

\section{The Pakistan Academy of Sciences}

In the afternoon of the first day of the Conference, February 16, we were present at the inauguration of the Pakistan Academy of Sciences, by the Prime
Minister of Pakistan, Al-Haj Kwaja Nazimuddin. $\mathrm{He}$ spoke of the heritage of scientific and cultural achievement in Muslim history and of the dark Middle Ages of the West, when Muslim scientists kept the spirit of scientific inquiry alive. The Government recognizes, he said, the importance of pure scientific research as the bed-rock of all important forms of development, and it welcomes the establishment of the Academy, which was destined to play a vital part in the life of the nation.

The nine Foundation Fellows of the Academy were then presented to the Prime Minister, and they later elected the following office-bearers : President, Prof. M. Afzal Husain, formerly vice-chancellor of the University of the Punjab; Secretary, Prof. M. Raziuddin Siddiqui, director of research, University of Peshawar; Treasurer, Dr. Bashir Ahmad, vicechancellor of the University of the Punjab. The other Foundation Fellows are: Dr. Nazir Ahmad, chairman, Tariff Commission, Pakistan Government ; Dr. S. Siddiqui, director, Scientific and Industrial Research, Pakistan Government; Dr. M. Qudrat-ikhuda, scientific adviser, Ministry of Defence, Pakistan Government; Dr. M. Ishaq, principal education officer, Pakistan Military Academy; Or. H. K. Bhatti, chairman, Department of Zoology, University of the Punjab; and Dr. M. Sharif, professor of zoology, Government College, Lahore.

The aims and objects of the Academy had been defined as the promotion of research in pure and applied sciences by means of publications, by the establishment of scientific libraries, laboratories, museums and research institutions, and by awarding grants, scholarships, fellowships, prizes and medals for research. The Academy will act as the National Research Council of Pakistan, for undertaking such scientific work of national or international importance as it may be called on to perform by the public and the Government. It will offer advice on all scientific matters to the Government and will represent internationally the scientific work of Pakistan.

Not more than five ordinary Fellows, distinguished for their original contributions to science, will be elected into the Academy each year until the limit of a hundred is reached. Eminent scientists of foreign countries will be elected as foreign members. These will be limited to thirty in number.

The Academy has already started work and plans are being prepared for the publication of Proceedings and research journals.

\section{OBITUARIES}

Prcf. S. N. Winogradsky, For.Mem.R.S.

WITH the death on February 24 of Sergei Nikolaevitch Winogradsky, science has lost the greatest figure in soil microbiology. Winogradsky was born in Kiev in 1856 and spent his childhood there. He was a student in the University of Kiev and, later, that of St. Petersburg, where he studied chemistry and plant physiology. There, after graduation in 1881, he investigated the effects of nutrient supply and other environmental factors on the growth of the wine yeast Mycoderma.

This early work was one of the pioneer investigations on the effects of specific nutrients on microorganisms grown in pure culture under adequately 